\title{
Observatório Permanente de Conflitos Urbanos de Campinas-SP: levantamento e análise dos dados a partir do noticiário local
}

\begin{abstract}
lago Vernek Fernandes (IC), Adriana Maria Bernardes da Silva (PQ), Resumo

O projeto consiste em compreender e investigar os conflitos urbanos presentes na cidade de Campinas-SP. O espaço urbano nesta pesquisa é compreendido através dos conflitos, buscando valorizar o seu potencial criativo, no sentido de estimular o debate entre cidadãos. Atentamo-nos ao estudo da urbanização de Campinas-SP e da mídia, buscando analisar comparativamente as situações geográficas conflituosas nos diversos espaços da cidade; esta que se forma por uma urbanização corporativa, onde o planejamento se faz voltado à satisfação das necessidades da grande empresa, ao mesmo tempo em que a população pobre se instala nas porções "opacas" do território. O resultado deste processo é uma cidade conflituosa, fragmentada, com muitos espaços pobres e uma desigualdade social elevada.
\end{abstract}

Palavras Chave: Conflitos Urbanos, Campinas, fontes secundárias.

\section{Introdução}

Este projeto de pesquisa se insere na proposta de implantação do Observatório Permanente de Conflitos Urbanos de Campinas, em curso no GEOPLAN/IG/UNICAMP, sob coordenação da Profa. Dra. Adriana M. B. Silva. Essa iniciativa, por sua vez, toma parte da rede nacional de Observatórios Permanentes de Conflitos Urbanos, sediada no ETTERN/IPPUR/UFRJ, sob coordenação do Prof. Dr. Carlos Vainer.

\section{Resultados e Discussão}

Procuramos demonstrar, a luz do conceito de urbanização corporativa, a relação entre conflitos urbanos e algumas situações geográficas presentes no espaço urbano, como: a fragmentação do território, a especulação imobiliária, a segregação dos pobres e os problemas urbanos. Para isto, recorremos à espacialização dos conflitos e à análise das variáveis-chave (objeto, agentes reclamado e reclamante e forma de manifestação) de acordo com as Unidades Territoriais Básicas (UTBs) de Campinas-SP.

Tabela 1. Objeto dos Conflitos Urbanos

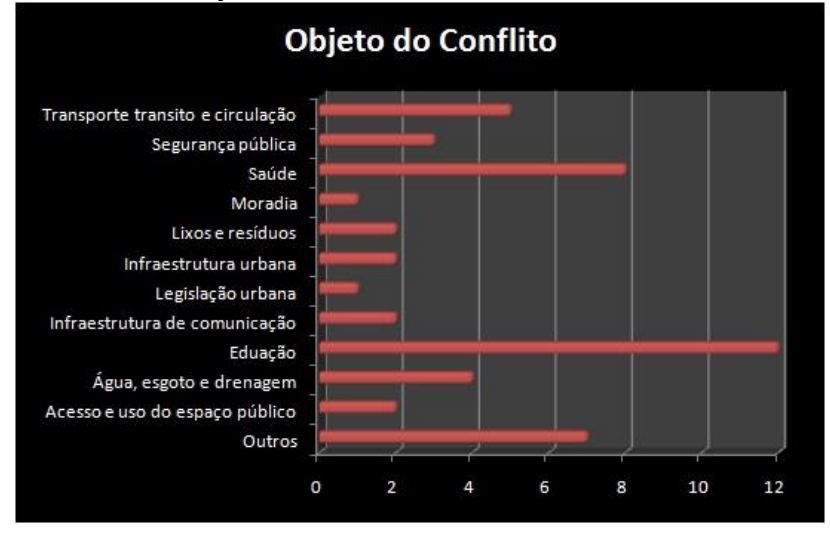

A tabela acima é um exemplo da sistematização dos objetos de conflito no ano de 2015. Estão contidas as variáveis que provocaram mais conflitos na cidade, ou melhor, as que foram mais divulgadas pela mídia: Educação, Saúde, Água, Transporte, etc. Atentamo-nos também à análise do modo de tratamento das mídias hegemônicas às manifestações coletivas que tiveram a cidade como objeto de reivindicação, além da relação desta com as mídias alternativas e movimentos sociais que debatem o direito à cidade.

\section{Conclusões}

Neste sentido, fica claro para nós que a mídia hegemônica produz informações para um público alvo, que não está nas classes pobres - a quem mais interessa a informação, já que está vetada dos principais espaços de debate político - mas sim nas classes abastadas, transformando notícia em mercadoria, informação em ideologia. Concluímos ao longo deste estudo que a mídia não retrata a real conflituosidade da cidade, tratando os pobres como marginais. Os conflitos periféricos ganham espaço na mídia apenas quando causam algum tumulto no espaço urbano.

\section{Agradecimentos}

Agradeço à minha orientadora Adriana pelos conselhos e reflexões despertadas e a todos que contribuíram com essa pesquisa, sobretudo aos integrantes do Observatório, em particular à geógrafa Helena Rizzatti. Por fim, agradeço ao $\mathrm{CNPq}$, que financiou a pesquisa.

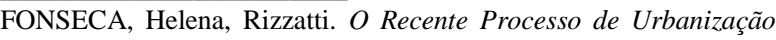
da Cidade de CAMPINAS-SP (1990-2014): As Ocupações Urbanas um Estudo dos Usos so Território da Região Sul, (Mestrado em Geografia) - GEOPLAN, Instituto de Geociências, Universidade Estadual de Campinas, 2014.

SANTOS, Antonio, C. Campinas das origens ao futuro. Ed Unicamp, Campinas 2002.

SANTOS, Milton. (1993) A urbanização brasileira. São Paulo: Edusp, 2005.. 